\title{
LA VERDAD POÉTICA: EL DÍPTICO HISTÓRICO DE BIGAS LUNA
}

Carolina Sanabria

\begin{abstract}
RESUMEN
El presente artículo tiene como interés central abordar la labor de adaptación literaria al cine tomando como referencia la obra fílmica de Bigas Luna en sus dos películas de época -La camarera del Titanic y Volavérunt- desde su eje obsesivo: la figura femenina. El director catalán se ha caracterizado, ante todo, por la búsqueda de interpretaciones del texto desde la incorporación de elementos personales de su filmografía y la delegación en el espectador del sentido, aunque en el primer film resulta provechoso y en el segundo contraproducente.

Palabras clave: Bigas Luna, La camarera del Titanic, Volavérunt, novela, adaptación.
\end{abstract}

\begin{abstract}
The present article has as central interest to approach the work of literary adaptation to the cinema by taking as reference the filmic work of Bigas Luna in two of his films. These are La Camarera del Titanic and Volavérunt and the analysis takes place from his obsessive point of view: the female character. The Catalan director has been characterized, first of all, by the search of text interpretations from the incorporation of personal elements of his films. Also he is known for delegating in the spectator the sense, although this is beneficial the first film and problematic in the second.
\end{abstract}

Key words: Bigas Luna, La camarera del Titanic, Volavérunt, roman, adaptation.

\section{Introducción}

Es bastante probable que la apabullante crítica negativa de Bambola (1996) supusiera un giro temático cuya radicalidad podría también haber movido -consciente o no- a su autor, el director de cine catalán más universal Bigas Luna, a modificar el tono tan explícitamente erótico que grosso modo venía caracterizando su producción anterior. "Las mejores escenas de sexo son aquellas en las que menos se ve", declararía años más tarde, más cauteloso, a la revista

Carolina Sanabria. Doctora en Comunicación Audiovisual y Publicidad de la Universidad Autónoma de Barcelona. Profesora de la Escuela de Estudios Generales. Universidad de Costa Rica, San Pedro, San José, Costa Rica.

Correo electrónico: csanabriacr@yahoo.com 
Fotogramas (Anónimo 2002: 96). Lo cierto, como quiera que fuere, es que la etapa siguiente de realización, una vuelta a las fuentes literarias en la elaboración de sus guiones, se decantaría por un erotismo más cerebral, más elucubrativo.

Ambos films constituyen lo que aquí se ha propuesto por nombre el díptico histórico: La camarera del Titanic y Volavérunt. En ellos, el director vuelve a las fuentes literarias, pero, a diferencia de Tatuaje (1978) de la novela homónima de Manuel Vázquez Montalbán, evade una adaptación menos literal y se lanza a una más creativa ${ }^{1}$-el primero como invención en torno a un hecho histórico (el naufragio del Titanic) y el segundo como alternativa a la verdad oficial (la muerte de la duquesa de Alba)- en la que incorpora elementos, elude otros, transforma significancias; en suma, genera interpretaciones bastante libres -de plena legitimidad en la adaptación fílmica (Sánchez Noriega 2000)-. Lo que, en definitiva, categoriza ambos títulos es la pérdida de la explicitud narrativa de las novelas originales desde una adecuación que favorece la producción de sentidos -un fomento de la ambigüedad que no hace sino estimular uno de los elementos más productivos y en ocasiones preciados de cualquier obra artística: la participación del espectador-.

\section{La maravillosa historia de amor de Horty y Marie o el triunfo de la creación}

La camarera del Titanic (1997) es un film que recurre menos a la exposición de los cuerpos que a los mecanismos mentales de la construcción del deseo. Tal representación del deseo que la película pone en imágenes la hace una de las más eróticas de las cintas de Bigas, aun cuando sea una de las pocas en que no aparezca un solo desnudo ${ }^{2}$.

En general, la recepción de crítica periodística local fue de sorpresivo agrado -sobre todo cuando escaso un año se había estrenado la respectiva coproducción italiana, vilipendiada por la prensa-: era inevitable que surgieran las comparaciones entre una película abiertamente sexual -“de excesos”, según el propio director (En: Martí Font 1996: 37)- con la inmediata, de atmósfera evocadora y poética -definida como romántica-, de un erotismo más bien mental, que vela y no expone, que sugiere y no explicita.

A partir de una lectura muy personal de La camarera del Titanic (La femme de chambre du Titanic, 1996), la novela del francés Didier Decoin, Bigas se acerca más a la adaptación como interpretación, notoriamente apartada del relato literario a la vez que deudor suyo en los aspectos esenciales (Sánchez Noriega 2000: 65). Independientemente de los decisores para rodar la cinta, su producción llegaría a coincidir con la del desmesurado largometraje estadounidense. El film terminó siendo así la involuntaria respuesta que vino a ser interpretada como la propuesta europea -estrenada unos meses antes- a la alternativa de la transnacional y ambiciosa industria hollywoodense, con la que contrastó no sólo en despliegue técnico y recursos económicos, sino en marketing 3 (Egurbide 1997: 34 y Llopart 1997: 41, 55). Por el contrario, en la producción italo-franco-española, la presentación del majestuoso transatlántico aparece totalmente desprovista de monumentalidad comparable: tan sólo un modesto montaje consistente en unos pocos planos generales del exterior (imagen más bien semejante a una pintura) seguido de unos cuantos del interior de una maqueta que quizás hubiera resultado ridícula para los encargados de la creación de efectos especiales del sofisticado equipo de Cameron porque las preocupaciones del director usamericano se centraban en la parafernálica recreación del hundimiento antes que en la historia que habría podido contar. En cambio, en la versión de Bigas, el colosal buque se reduce a ser apenas el telón de fondo de lo que ocurre, donde el conflicto no se centra precisamente en la pérdida de vidas. 
La película recupera mucho del tema realidad-ficción de Angustia -a su modo, un antecedente-, pero no desde el thriller, sino desde la complejidad del amor y de los celos. El habitual triángulo (pues el conflicto se estructura, una vez más, en una relación conformada por un trío) se presenta con una ligera variante: Marie, la tercera en discordia, no existe. Al menos no tiene existencia real (¿y qué ser amado la tiene? ¿en cuál persona querida no se idealiza -más bien, se ficcionaliza- su imagen?), no como la imagina Horty, el retraído y lejano trabajador de la Fundición Simeón, quien, tras una breve ausencia para asistir a la partida del Titanic, se entera del rumor de que su esposa, Zoe, ha mantenido relaciones sexuales con el presidente de la compañía. A partir de entonces, e incitado por sus amigos y compañeros de copas, se anima -y lo animan- a narrar en el bar una historia de amor entre él y una misteriosa mujer que conoció la víspera de la salida del trasatlántico. Es aquí donde se produce uno de los muchos juegos entre realidad y ficción, porque las imágenes de la película sólo presentaban lo sucedido hasta el momento en donde ambos desconocidos se reunían en la cama. Mediante la elipsis, esta imagen aparecía fundida a otra que -¿sueño, deseo o realidad?- mostraba el primerísimo plano de una arrobada Marie, susurrando repetidas veces el nombre de Horty: ello daba lugar a una nueva disolvencia, a la mañana siguiente, cuando éste despertaba, solo en la cama. El empleo de esta forma de paso abunda en la cinta, pues la película se construye a partir de evocaciones, deseos y ese regreso al dolor que -parafraseando a un célebre cantautor popular- supone la peor de las nostalgias: añorar lo que nunca jamás sucedió.

Tras su retorno, ya en el bar, el joven se repliega a ese momento y el film procede a una enunciación (verbal) de su discurso para reemplazarlo poco después por un flash-back, donde desfilan unas imágenes que se organizan en torno a su narración. La camarera del Titanic recurre a esta estrategia en un afán de contribuir a la ambigüedad a partir de una arrebatadora historia de amor y pasión de la que no se sabe con rigor -y tampoco importaqué es invención y qué realidad -ya lo advierte un sonriente Orson Welles en la introducción de Fraude (Fake, 1973): "Todas las historias tienen algo de mentira"-. En la misma tesitura funcionan, como referentes y/o estrategias de construcción discursiva, los fragmentos evocadores de los cuentos clásicos de hadas -"La bella durmiente"-: "Respiraba pero ya no decía nada... yo no sabía cómo despertarla [...] Nunca había visto una mujer tan hermosa [...] Estaba muerta. La besé y la resucité con mi lengua", vinculación casi imperceptible a pasajes de la narrativa infantil que constituye, en la filmografía de Bigas Luna, una constante ligeramente sensible. No sin razón Baudrillard afirma que el amor nunca ha sido tan hermoso como en las leyendas y las novelas (1997: 117).

Tan cautivadora es la narración que reúne poco a poco en el bar a una cada vez mayor cantidad de concurrentes para escuchar lo que cuenta. La fascinación es tal que suscita curiosidades, preguntas, todo lo que permite abrir nuevas vetas y posibilidades de creación sobre un relato que se produce en la misma performance, en el mismo acto de narración, sostenidas en buena parte por la natural cuota de morbo que reside en cada espectador ("Venga, cuéntanos cómo fue debajo de la mesa", "Mejor lo de la pasarela, cuando la cogiste por detrás", "No, lo de debajo de la mesa era mejor”, “Cómo tenía el conejo?”, "Sí, el conejo”, "Cuéntanos lo de la mesa", “iLo de la pasarela!”). Este aluvión de peticiones constituye más bien contribuciones que, desde la colectividad, permiten orientar y construir un relato que deja ya de ser individual ${ }^{4}$. Pese a que el hecho ha sido vivido por Horty, el relato no le pertenece sólo a él, sino a quienes escuchan, aportan y se identifican, en definitiva, a quienes lo asumen. A nivel de recepción, el lazo de cohesión de este colectivo recrea el mecanismo de la afición popular que, a través de su catarsis, revive la construcción de un género: el melodrama seriado. 
Horty, con los silencios oportunos de la narración y su suspenso dosificado, alimenta en sus ávidos escuchas un interés por los más minuciosos entresijos, por los más mínimos intersticios no gráficos, no de cuerpos, sino mentales.

$\mathrm{Su}$ éxito es tal que el número de asistentes aumenta paulatinamente hasta que las esposas notan el cambio en su intimidad -sus maridos, insuflados por las proezas del joven minero, renuevan (o inventan) la pasión en sus hogares-: el discurso tiene la propiedad de modificar, de alterar la realidad. En un lugar pobre, prácticamente premoderno, donde el trabajo es difícil y la vida dura, la gente necesita entretenimiento. Sin radio -al menos no hay mención-, sin literatura -pues la población de inicios de siglo era mayoritariamente analfabeta-, sin cine -que llegara todavía a masificarse como industria cultural-, en suma, sin más recursos de ocio que las inhumanas competencias organizadas por los propietarios de la compañía, el lirismo que rezuman las palabras de Horty procuran a los trabajadores una distracción en su monotonía, un sentido a sus impasibles vidas cotidianas que los hace descubrir y participar de las posibilidades de complacencia como de imaginación que ofrece la narración. Desde Homero, la necesidad de escuchar historias ha sido un hecho común que ha cautivado a la humanidad. El relato conjura otros mundos y, desde la oralidad, tiene la facultad de complacer a todos -a partir de un mismo referente (la palabra), cada cual crea su propia significación-, así como de congregar e integrar.

Aedo moderno, Horty además participa de cierta sensibilidad que lo separa del resto de los trabajadores de la fundición -sus ademanes y miradas se corresponden a las de un hombre ensimismado y soñador-, que se define ante todo por su entrega de espíritu ${ }^{5}$. Comparte, como personaje feminizado, la naturaleza que social y culturalmente se le ha conferido desde otras latitudes a la mujer sobre el ejercicio narrativo -Scherezade en los ancestrales relatos orientales y Eva Luna en la literatura latinoamericana contemporánea-. Pero a pesar del poderoso sustrato sexual, su historia mantiene un trasfondo amoroso. Y aunque los amigos del bar demandan, no sin reiterada insistencia, pormenores sexuales, Horty incluye también los entretelones de una idealizada y dosificada historia de amor: las imágenes que evoca su relato muestran a la pareja bailando un vals en el Titanic, escondidos bajo la mesa del comedor, besándose repetidamente. Detalles de este tipo aseguran a la vez que alimentan la audiencia femenina, proclive a la verbalidad y a la ritualidad del cortejo (Gubern 2000: 172), sin descuidar las novedades sexuales que consolidan la fidelidad del público masculino. "¿Estás seguro de lo que dices, Horty? ¿Doce veces?”, se admira uno de sus amigos, ante lo cual, éste, henchido de complacencia, suspira y asiente categóricamente: “Doce veces!”, pero de inmediato matiza: "Ella me decía, 'Horty, sería maravilloso morir de amor... morir de amor". El éxito de la historia obedece tanto a una innegable capacidad de oratoria como a una construcción narrativa que contiene en su seno los cimientos de la literatura pornográfica (el detalle íntimo) y del melodrama (la serialidad y el suspense).

Pero sin duda el idealizado relato no es narrado tanto para los otros como para sí y no sería ilícito pensar que a Horty le interesara menos persuadir a los demás de la verosimilitud de su historia. Porque si bien el con-vencimiento del otro ha figurado como una de las motivaciones de la palabra, en este caso se dirige, ante todo, a él mismo: el mayor de los retos de Horty está en creerse su propio relato, asentado en la adulteración de los hechos, que es donde reside el pathos de la creación. Y en el proceso simultáneo de invención y transmisión de la historia, termina enamorándose de una mujer a la que no conoció más que por haber dado cobijo en su habitación. La situación es, sin embargo, compartida: él también resulta un desconocido para ella. En realidad, ambos no son sino un par de extraños -circunstancia no 
por cierto infrecuente en las relaciones humanas-, como sugiere la evocación, a nivel pictórico, del óleo de Magritte, Los amantes (Les amants, 1928), en el que, metáfora del amor, la pareja se besa aunque sin poder contemplarse los rostros porque tienen sus cabezas cubiertas -se desconocen, son extraños el uno para el otro: "amo al que supongo conocer"-.

La economía personal mejora cuando la demanda de concurrentes aumenta a tal grado que se acuerda un beneficio monetario a partir de las propinas del bar a cambio de que ejerza formalmente su oficio de contador de historias, con lo que su fama se extiende a otros rincones. De uno de esos remotos lugares procede Zeppe, un teatrero ambulante que termina reclutando al ya desempleado Horty en su pequeña compañía itinerante, previa autorización de Zoe -la cual en la novela no aprueba la decisión de su esposo y, por tanto, no participa del espectáculo-. Poco a poco la representación se depura y Zeppe y compañía recurren a técnicas -materiales y retóricas- para sofisticarla: "Con un lápiz en la boca y una cebolla se hacen milagros”, había sido la primera lección al conocerlo. Este espectáculo errabundo que está en todos los sitios y a la vez en ninguno se nutre de los más variados recursos para promoverse, entre ellos, el viejo sistema de pregoneo que anuncia a la vez que extracta la historia, como lo hace, entusiasta, el propio Zeppe, con su acento característico: “¡Vengan a escuchar la maravillosa historia de amor de Horty e [sic] Marie que tuvo lugar en el gran Titanic mientras naufragaba en los hielos del polo norte!" -enunciado que acusa una flagrante ficcionalización de la realidad-. Con el éxito, sobrevienen las ganancias, y con éstas, la utilería se refina: láminas de metal para simular el sonido de las olas, cuernos para imitar el bramido del buque, música para ambientar y conmover, figuras como cupidos deslizantes en hilos invisibles o la imagen de Marie en un panel a tamaño natural -de la cual Zoe reclama, sin éxito, su retiro-, ampliada a partir de la fotografía que, desde su regreso de Southampton, Horty portaba siempre consigo.

En uno de los primeros -y más controversiales- films del mismo director, Bilbao (1979), la fotografía se constituía como una imagen que evocaba a la muerte. Pero en este caso cumple otra función: motor e ilustración de la historia. Bruno Latour sostiene que en la descripción de un objeto se hace necesario mostrarlo si se quiere lograr efectos considerables en la construcción de cualquier hecho -ya que, a diferencia del texto (verbal), la imagen no es (al menos en aquel momento) susceptible de adulteraciones (1998: 95)-: así, la fotografía de Marie deviene la constancia de su existencia. Y aunque en el texto de Decoin los oyentes de la taberna son algo más incrédulos, en el film de Bigas ninguno se permite el lujo de la duda -la ficción, ya se dijo, es el único subterfugio de su monotonía-: se está ante una constatación gráfica que por convención social da cuenta de la verosimilitud de su relato, lo que facilita que se opere el hechizo colectivo de la historia.

Pero ante el protagonista mismo el retrato de Marie cumple otra función. La fotografía es una materialidad concreta que suele adquirir un valor afectivo: "Todo lo que es imagen tiende en un sentido a hacerse afectivo, y todo lo que es afectivo tiende a hacerse mágico" (Morin 2001: 36). Demarcador de su idealismo, la ampliación de la imagen es física para revelar que mentalmente también lo es -la proyección materializada del deseo de Horty-; un icono cercano a los dioses que da cuenta de su existencia al mismo tiempo que exige veneración. De ahí que su impresión inicial de Marie tenga una correspondencia divina -no sólo su nombre, sino la expresión de su rostro y el atuendo (el manto) virginales de su primera visión- ${ }^{6}$.

En cambio, en el film, conforme crece la popularidad de la función, la recelosa Zoe aumenta su malestar al ver a su esposo vertir públicamente su sentimentalidad sobre otra mujer, aun cuando la sepa muerta o -peor aun- inexistente. Desde el espacio inmaterial en el 
que se construye la ausencia, Marie se configura como la figura antitética de la esposa -esto es, de la mujer real-: la ideal, la amada, la que no decepciona porque no engaña, porque no discute, porque no se queja, porque no exige, porque simplemente no existe -es una invención-; en suma, la mujer ángel.

Esta alteración en la vida de Horty se refuerza con el uso de las tonalidades de los distintos momentos: a partir de la irrupción de Marie se impone un cambio en la visualización del color. En una primera parte -la actividad en la mina- privan las tonalidades blancas, negras, grises y marrones, evocadoras de la atmósfera inicial de Germinal (1885) de Zola (Casas 1997: 53) y utilizadas para destacar la monotonía del medio y la sombría existencia -laboral y personal- de los trabajadores ${ }^{7}$. Poco antes de la aparición de la camarera -la llegada de Horty a Southampton-, se amplía el rango de coloraciones para anunciar el cambio de una vida no sólo repentinamente mudada a la trashumancia y al éxito en la oratoria, sino más intensa y apasionada. De ahí que se destaque que la joven, que no lleva pintalabios -impropio de una mujer ángel-, le prometa que lo usará por él; así como el posterior disgusto de Horty al ser recibido por una Zoe con los labios carmesí: su esposa es definida por el gris, mientras que el rojo sólo puede ser significante -mejor aun, monopolio- de una inconmensurable Marie. El entusiasmo de Zoe contrasta con la actitud abstraída de Horty una vez aceptada la propuesta de Zeppe mientras van camino a lo que su esposa llama una nueva vida: a partir de esa secuencia, los colores se encienden aún más. Pero en las últimas escenas de la película -las correspondientes a la reaparición de Marie- tienden a dominar las tonalidades frías, azules, en consonancia con el océano, marco donde -según el relato de Horty- tiene lugar el reencuentro final. En inglés, el azul expresa algo más que uno de los colores primarios: señala un estado anímico de abatimiento y un nostálgico ritmo (el blues) surgido en los Estados Unidos como forma de expresión -que los inmigrantes provenientes del continente africano transmitieron a sus descendientes por el dolor y la añoranza, por el sentimiento de pérdida del lugar de origen-. Por eso, la vivacidad anterior de colores era tan sólo externa, aparencial, porque el hundimiento del Titanic acaso haya marcado también el hundimiento personal de Horty en el lugar en donde la imaginación se resiste a ser sustituida por la realidad y el olvido para conservarse en la memoria, esto es, en esa "insidiosa nostalgia que poco a poco se ha ido apoderando de nuestra memoria, es decir, de la memoria activa, aquella que corresponde al mecanismo y al deseo de recordar" (Català 1993: 33).

Habiéndole insistido su esposo en la falsedad del supuesto desliz -como suele ocurrir en casos donde efectivamente los ha habido-, las pretensiones (pecuniarias) de Zoe la llevan a aceptar -aunque no de muy buena gana- que Horty narre la historia, eso sí, incorporando paulatinamente sus exigencias y presencia en el espectáculo, hasta llegar a interpretar la muda figura de Marie, en una nueva elaboración -desde Bilbao- de la objetualización de la mujer: la musa. Fiel a sí mismo, este intercambio de papeles es parte de las modificaciones quizá más apreciables de Bigas al texto original, que suprime algunos pasajes y personajes secundarios ${ }^{8}$, construye otros -como a Pascal, el esposo de Marie, una variación del despreciable Mr. Cheapman aunque con escaso desarrollo- y le concede mayor importancia a los personajes ya existentes, como el de Zoe -que en la novela se recluía, herida, en su dolor y expulsaba al marido de la casa-. En la versión cinematográfica, hay una connivencia que supera el radicalismo sentimental ya planteado desde su anterior Lola (1985), pero se plasma de manera mucho más representativa con la intervención de la esposa en la puesta donde literalmente asume el lugar de la otra -que, en definitiva, es a la que se legitima como la propia-. Ciertamente la Zoe de Decoin, en sus relaciones con los personajes masculinos -mayor descaro con Simeón 
pero más decoro con su propio esposo-, no es comparable con la de Bigas, lo que quedaría en parte matizado si se toma en consideración que en el film actúa bajo la variable monetaria. Aun así, presa de los celos, ejerce su propia lucha en todos los niveles. Intenta -en la ficciónocupar el lugar de Marie y trasladar -a la realidad- la narración de su esposo: “A partir de hoy me pintaré todos los días los labios!... como ella", y más adelante, le pide: "Hazme el amor como a ella". "Nunca he hecho el amor con ella", le responde él. "Entonces, como lo cuentas...". Una vez más, no sólo la ficción necesita de la llamada realidad para construirse: la realidad se ve contaminada por la ficción.

Con cada puesta en escena, con cada público, la historia inicial se modifica. Pero tras la interposición de Zeppe, el espectáculo -que con la itinerancia ha perdido el carácter seriado de sus inicios- llega más tarde a presentarse bajo el ampuloso -y mentiroso- título de Horty, el superviviente del Titanic: así, Horty pasa de narrador a partícipe, de autor a actor, como diría Kristeva (1978). En la clausura de la actuación, éste terminaba conjurando, al igual que en el psicoanálisis lacaniano, la capacidad de curación, casi mágica, por medio de la palabra, donde el psicoanalista es colectivo y el paciente no está en el diván sino en el escenario: "Y desde ese 15 de abril me consuelo hablando de ella", murmura, inundado de abatimiento, con las palabras que cierran cada función (y que asimismo concluyen el film). Además, es en él en quien recae la función de narrador que de modo semejante retomará, con el componente de reproducción -que no de invención- el Ulises de Martina de Son de mar (2001)9.

El film logra sostener la incertidumbre entre el relato de Horty y lo que verdaderamente acaeció hasta la imprevista aparición de la figura de una Marie, que -contra lo que aquel pensaba (y relataba)- había naufragado. A partir de aquí se reconoce que la historia era la invención de un joven vacilante entre el impacto por la belleza de la camarera impostora y los celos por los rumores -que participan de la misma naturaleza incontrastable- hacia su esposa (y hacia su propio orgullo herido) ${ }^{10}$. La irrupción de Marie desmitifica la imagen de la mujer candorosa que Horty había construido: lejos de ello, se trataba de una prostituta que, en confabulación con otro -su marido Pascal-, había recurrido a la situación de indefensión y desamparo -de gran efectividad entre los hombres- en donde pedía alojamiento para luego robar. Si bien el primer propósito resultó exitoso, no corrió con la misma suerte en el segundo, porque el elegido resultó ser un muchacho pobre cuya estancia en el lugar no respondía más que al cobro de un premio. Con ese mismo interés, enterados después del popular espectáculo, la pareja viaja para reclamar su porcentaje de participación en la historia, hasta que, en plena actuación, ella se levanta y se deja ver entre el público del teatro.

Prostituta y ladrona, es ya común en Bigas Luna esta construcción del personaje femenino a partir de las variaciones entre ángel y demonio -que evolucionan hasta llegar a permutarse-. La ambigüedad de su identidad se refuerza incluso en la nominación -Marie, Sandra o Beth, dependiendo, según Pascal, de cada cliente-. Además, en tanto objeto de proyección de atributos imaginarios de otro (Horty) -lo que en definitiva responde a su propio deseo, puesto que el enamoramiento entraña, como da cuenta el mito de Pigmalión, cierta vanidad personal: "el texto amoroso [...] está hecho de pequeños narcisismos, de mezquindades psicológicas" (Barthes 1997: 195)-, Marie participa de la condición doble de mujer real e ideal.

A ese respecto, Fernández-Santos llamaba la atención sobre "un balbuceo en la zona de desenlace" (1997: 43) que no define pero que podría apuntar a la misma idea que Victor Flury detallaba en una columna de crítica. Para éste, la reaparición de Marie determinaba 
el momento en que la película perdía la fuerza inicial, en tanto suponía una resolución de la ambigüedad que hasta entonces se había logrado sostener -y sugería al espectador olvidar lo que acontecía a partir de ese momento-:

\begin{abstract}
Por eso, uno lamenta que la película, cerca del final, ceda a la tentación explicativa. Cuando Marie aparece en público, Bigas Luna tuvo la oportunidad de hacer estallar el cine. ¿Y qué hizo? Nos pasó todo en limpio, prolijito [...], echando por la borda lo que urdió con tanto esmero y genio: los límites difusos entre invención y hechos. Pero, en fin, creo que uno puede olvidar -si se atiene a lo visto- la última puntada del bordado y quedarse con la semirrealidad que nos ató a la butaca la mayor parte del tiempo (s. f.: s. p.).
\end{abstract}

Si bien se está ante una afirmación válida, no resulta suficiente. De ningún modo todo queda resuelto: Bigas deja pendiente a la imaginación del espectador algunos hechos, como la conversación que Horty, tras abandonar el teatro, debió sostener con ella. En el texto literario, el contacto era más desencantado, con una Marie desprovista de su halo de pureza y misterio, más calculadora e insensible, prosaica hasta en su muerte -de un golpe en la nuca en la bañera a la espera del cobro-. Pero a partir de su aparición en el teatro, la adaptación modifica totalmente el desenlace: él interrumpe la función para precipitarse en su busca. Sin embargo, el encuentro sólo se presenta hasta el inefable y prolongado intercambio de miradas, en el que ninguno de los dos emite una palabra. Y una vez más tiene lugar la elipsis, donde la película suprime la narración (las imágenes) de lo ocurrido, que parece recuperarse sólo cuando el joven regresa al teatro, confesando que el relato anterior era una mentira y anunciando que esta vez sí se referirá a la verdad. Como antes, las imágenes que transcurren en el flujo fílmico se confabulan con el discurso para ilustrarlo: es cuando tiene lugar otro flash-back que, al igual que el anterior, responde a una disposición meramente subjetiva. Con ello, tanto el personaje protagónico como su creador hacen uso del mismo recurso de narración: la imprecisión de la historia.

Es así como entonces la única constancia de los hechos se tiene por boca de Horty pero, dados sus antecedentes en lo que atañe a su veracidad -que no a su elocuencia-, no es fuente fiable. La única certidumbre que queda de su relato es que la tragedia del Titanic no costó la vida de Marie, sino la imagen que de ella se había construido. "Está muerta", señala en su iúltima? presentación, "He matado a una mujer que se llamaba Marie y que no era la que yo había amado en Inglaterra. La he devuelto al mar que la había deseado. Irá a reunirse con los restos del Titanic y con todas las cosas que duermen en el fondo del océano. Nunca volveré a verla”, de gran similitud en entonación y contenido -que no en lirismo- con el imperturbable susurrar de Leo"11: "No respiraba. Está muerta. Todo mi mundo se ha destruido. Otra vez me siento en la realidad". Mientras que a Leo la muerte de Bilbao lo jalona hacia la realidad, a Horty, la pérdida de Marie le permite alejarse, delirar en un discurrir sin término: en ambos casos, Bigas presenta la realidad como una monotonía, aunque en este caso lo aborda desde la ficción creadora como fuente de evasión.

Según la nueva versión de Horty, Marie vuelve a morir ahogada. La muerte ficticia en las aguas se combina con la simbólica mediante el uso de otro de los elementos primordiales: el fuego (representación del principio de la vida) (Eliade 1988) de donde él mismo proviene (de una fundición) con que quema (forma de purificación) al ídolo. "Sólo hablaré de Marie conmigo mismo, de mi Marie, de la que está en mi pensamiento", concluye, aunque la cinta deja abierta la posibilidad de que se trate de una estrategia (más) de narración. De cualquier forma, son palabras que remarcan su victoria personal frente a una Zoe derrotada que, ante los frenéticos aplausos, no acude, como siempre, con Zeppe y el pequeño maromero Joan, al escenario, ni tampoco es capaz de sostener, desde los bastidores, la mirada de Horty, que 
ha concluido felizmente su aprendizaje de intérprete. Sin embargo, el film es un triunfo de la subjetividad, una reivindicación de ese placer íntimo, insumiso, artilugio de rebelión contra una realidad aplastante que Bigas defendía en la sexualidad de Claudia y Marta en Huevos de oro (1993), pero esta vez trasladado a la imaginación y la invención narrativa, a la creación perpetua.

Por tanto, la mayor contribución al texto literario reside en la conformación de la atmósfera de vaguedad. Mientras que en la novela se sabe, desde el momento en que los dos personajes pasaban la noche juntos, que no había tenido lugar contacto sexual, en la interpretación cinematográfica domina la ambigüedad en la imagen -propiedad inherente-, al igual que en el discurso de Horty -impreciso, falaz-. Siendo de conocimiento común la vaguedad de la palabra, La camarera del Titanic cuestiona la transparencia de la imagen, la cual 'a menudo parece 'querer decir' más cosas, ser intercambiable con otras y guardar en su interior ciertos [sic] interrogantes e incertidumbres" (Casetti y Di Chio 1998: 72-73). Lo que ello permite inferir, en definitiva, es una distinción tradicional que está a la base de las articulaciones del texto y de la imagen: la palabra (unidad básica del texto) parte de significados muy precisos, pero las connotaciones que engendra derivan en la ambigüedad (lo poético), mientras que la imagen tiene su punto de partida en esa condición indecible, irreductible a la lengua que la lleva a alcanzar igualmente una consistencia semejante (lo poético) puesto que requiere de otro referente inicial de naturaleza idéntica para traducirlo (Català 2002).

Así, la película conserva la duda de las circunstancias en las que el dije de salamandra ${ }^{12}$ pasó a las manos de Marie, de lo que se dijeron y/o hicieron, de si las imagenes finales del apasionado beso en la playa habrían sido parte de un recuerdo o -una vez más- de la imaginación y el deseo de él y/ o de ella -quien, afectada por el reencuentro, se muestra turbada, distante, lejana (“Pero, ¿por qué pones esa cara? Tenemos el dinero, ¿no?”, le pregunta Pascal en el coche y, tras una palmada de complicidad sin reacción, insiste: “QQué? ¿Te gustaría que te tocara él? ¿Es eso?... Nunca me convencerás de que no pasó algo entre tú y ese pobre tipo")-.

El film, en suma, recupera ese placer por la narración que en muchos queda pendiente, para que, en calidad de historia inacabada, se complete por los deseos y el imaginario del espectador (Vanoye 1996: 30): justamente es ese el punto donde se genera el involucramiento, la participación productiva del espectador que contribuye con nuevos e insospechados sentidos. Evidenciando así las limitaciones de la certitud de las imágenes y de la transparencia de las palabras -como dan cuenta el narrador y su autor real-, La camarera del Titanic formula la transitoriedad de las certezas y descubre los signos que, desde sus imbricaciones, desde su polivalencia, terminan, como Marie, descolocándose (dis- locándose).

\section{El thriller histórico}

\subsection{Una superproducción de lujo}

Volavérunt (1999) es una adaptación libre de la novela homónima (1980) del escritor uruguayo Antonio Larreta, ganador del Premio Planeta. Prácticamente la totalidad de las reseñas y críticas periodísticas coinciden en resaltar la labor de reconstrucción histórica, donde es evidente la apreciable inversión de capital en vestuario y localizaciones de restauración de 
cortes -1.200 millones de pesetas, 400 menos del presupuesto de La camarera del Titanic (Bonet Mojica 1998b: 60)- conforme a lo que muestra la recreación comercial -plena de esplendor y lujo- que usualmente requiere una producción histórica ambientada en las cortes -en este caso, españolas del siglo XVIII-. El resultado es un entorno cargado de las texturas más vivas y brillantes -como las estancias y el rojo intenso de los divanes- que se hayan visto en cualquier otro film del director. Para el rodaje, Bigas contó con la colaboración de un sólido equipo técnico, dentro del que sobresale Paco Femenía en la iluminación (que abunda en luces de acentuación en pequeños detalles -como forma de realzar la opulencia que reinaba en los castillos-). Este prestigioso director de iluminación acumulaba a su haber la experiencia que le había deparado su participación en otra cinta de época, A los que aman (1998), de Isabel Coixet. El vestuario, por su parte, corrió a cargo de Franca Squarciapino -que en 1990 había obtenido un premio Oscar por su trabajo en Cyrano de Bergerac, de Jean-Paul Rappeneau-, quien se encargó de 1.500 trajes realizados en los talleres de Madrid, Milán, Pompeya y París, y otros tantos pares de zapatos, sin mencionar los miles de sombreros femeninos, plumas, tricornios y joyas (García 1998: 9).

Con este esmero en la ambientación y un cambio favorable al high-key, Volavérunt evidencia ya claros distanciamientos técnicos con respecto al cine inicial -la etapa negra-, entre cuyos aspectos sobresalían la austeridad de medios, la fotografía prácticamente casera, con grano, la iluminación oscura o el viejo predominio de primeros planos, primerísimos y de detalle: una inscripción -cada vez más lejana- en la tendencia vanguardista de los años sesenta que desdeñaba las apariencias costosas e independizaba la pobreza material de la espiritual (Tyler 1973: 38). Se trata de un resultado comprensible en vista de la actualización del lenguaje y de la evolución de los medios de filmación.

\subsection{Vida y pasión de Cayetana de Alba}

La historia gira en torno a un fragmento de la vida de Francisco José de Goya y Lucientes, una figura que había estado presente en la producción fílmica de Bigas Luna como de otros cineastas del cine de oposición después de Franco (Saura, Buñuel). Sus representaciones contenidas de violencia política y sutil crítica social han hecho del pintor uno de los artistas plásticos de mayor influjo -de ahí que los premios nacionales que otorga anualmente la Academia Española de Cine llevan la efigie y el nombre del pintor más popular (considerado el precursor de la pintura moderna) y más cinematográfico-. Pero a Bigas le interesa no sólo la dimensión visual de sus cuadros como su potencial como personaje: si en Caniche (1979) o Jamón jamón (1992) se distinguen algunos planos construidos a partir de las obras del pintor, en Volavérunt -donde también los hay ${ }^{13}$-, Goya figura ante todo como parte de la historia, la cual gira en torno a las relaciones cortesanas en las que participó y que favorecieron parte de su producción bajo mecenazgos de la realeza. Pero aun antes que Goya, Bigas parece preferir la complejidad -social y sexual- de Cayetana, la duquesa de Alba, de quien, según la tesis que recogen la novela, la película y el discurso popular, estuvo enamorado. Más independiente pero no menos pasional que los tradicionales personajes femeninos del director, en el romance que sostiene con Manuel de Godoy, Cayetana se resiste a ser tratada como objeto (manipulable) -Bigas la inviste de un matiz de rebeldía-, sin por ello dejar de representarse como una mujer enamorada. Sin embargo, según la novela y el film, su relación con el ministro la arrastra a su perdición -y una vez más, la mujer se configura como el lugar donde se reúnen sexualidad y muerte-. 
La imagen que fundamenta la obra (literaria y fílmica) proviene de uno de los más polémicos y reproducidos óleos -La maja desnuda (1799-1800), quince años después condenado por la Inquisición-, pero el título está tomado de uno de los grabados (perteneciente a los Caprichos) donde la duquesa se asimila al "prototipo de la veleidad de sentimientos, como bruja voladora" (Paas-Zeidler 1980: 18). El arte se revela así como forma de inmortalización: mientras que en La camarera del Titanic se lleva a cabo a través de la fotografía, aquí se logra por la pintura -dos medios donde la presencia se desvanece y deja paso al recuerdo para terminar ocupando el lugar de la falta-. Y en su intención de suplantar al referente, la imagen llega a superarlo, la representación se eterniza.

En la novela, el grabado en cuestión cobra dos significaciones destacables: por un lado alude a los efectos que producían en la duquesa los polvos de los Andes que consumía, como explica (¿presagia?) el propio pintor:

\footnotetext{
La maja lleva muy ufana una gran mariposa en la frente que parece arrastrarla en el vuelo hacia alguna región de delicias e ignora los monstruos que se agolpan y acechan a sus pies. Pero los monstruos terminarán por triunfar (Larreta 1999: 108).
}

La otra interpretación proviene del obispo Luis de Borbón y Vallábriga, para quien la imagen representa un retrato del alma atormentada de su hermana María Teresa (Mayte), condesa de Chinchón y esposa de Godoy ${ }^{14}$. La adaptación añade un sentido no previsto por la novela: volavérunt es la figura poética -la sinécdoque- con la cual Cayetana designa su propio órgano sexual -de donde popularmente fue conocida como "el coño de España"-. Presentada como mujer de sensibilidad y sexualidad no adecuadas para su época, la película escudriña los resquicios de su intimidad, permitiéndose licencias extraídas de la aportación personal de su director como los desmayos que sufre después de cada orgasmo ${ }^{15}$ o la moderada referencia (sin mostración) de la depilación de su sexo -que sí se visualiza en Bilbao y Lulú- destinada a presentarla como una mujer adelantada a su época ("Me he depilado", le dice a Godoy: "Es una moda francesa"). El término, como lo interpreta Bigas a la manera de una suerte de juego etimológico, propone una personal segmentación silábica, de acuerdo con un artículo suyo publicado a raíz del estreno del film:

\footnotetext{
VOLA, de volar, es la primera etapa, en la que los personajes hacen volar sus fantasías, sus amores, deseos, pasiones [...] Esta época sería sensual, divertida, llena de luz, de ironía y conoceremos la parte sensible de los personajes.

VER, de ver, de mirar, ¡de vivir para ver! [...] Es la parte de las intrigas, los rencores, las manipulaciones, las pequeñas venganzas, las relaciones más perversas... todos siguen amándose, pero todos desconfían de todos [...]

UNT es la parte del gran misterio: ¿quién mató a la duquesa? La intriga. El suspense. Un asesinato bello, construido sobre la espiral de lo siniestro, de los odios y las venganzas (1999: s. p.).
}

Según el Diccionario de la Real Academia de la Lengua Española, la significación de volavérunt proviene de una voz latina derivada de volare que tiene un uso festivo para significar que una cosa falló del todo, se perdió o desapareció. Precisamente ésta es una historia de extravíos que tiene lugar en un ambiente cortesano sólo en apariencia jovial: pérdida del amor -que, con la excepción del de Goya hacia Cayetana, es más bien volátil-, de las joyas de la duquesa, del frasco de verde veronese, de la identidad de la modelo que se diluye en el cuadro...

De hecho, semejante a La camarera del Titanic, se mantiene -aunque ciertamente desde un distinto tratamiento- el tema de la confusión de identidades, al recogerse los rumores 
populares -vigentes hasta hoy- de que la retratada en cuestión habría sido Cayetana de Alba. La tesis de la novela (que suscribe la película) es que Goya pintó el célebre cuadro a partir de la imagen de Pepita Tudó, la supuesta modelo, combinando algunas partes de la imagen que tenía ante sus ojos con las que habría recordado del cuerpo de la duquesa: vuelta al juego de ocultamiento de identidades, a la realidad que se cuela en el arte y a la experimentación (doble) del placer de la mirada (en la pintura y en el film) -lo que remite a la relación entre la composición de la obra con el ojo del espectador (Aumont y Marie 1993: 10) que como tal se había trabajado más formalmente en Angustia (1986)-. Es una interacción que no se restringe a la expectación, sino al acto mismo de creación, lo que permite escenificar la relación entre el referente real con la memoria que se amplía a la imaginación. Inseparable del mito, la memoria es la madre de la creatividad, dice May: "La memoria es el escenario interno en el que dejamos volar la imaginación, en el que creamos ideas nuevas y a veces espléndidas" (1998: 67).

De modo que si en Tatuaje el esclarecimiento del delito es delegado a su famoso protagonista, Pepe Carvalho, aquí el detective no es otro que el espectador, testigo de un crimen que se convierte en enigma: la autoría y las razones del (de los) asesino(s) de la duquesa. La novela inicia reproduciendo la versión oficial: la hipótesis del suicidio -tal y como históricamente lo consignaron los médicos a la policía que levantó el informe-, para rebatirla cuarenta años más tarde, cuando Goya, presintiendo la inminencia de su muerte, le confía a Godoy sus sospechas de un homicidio (por envenenamiento de pintura) en el que el involuntario autor habría sido él mismo. Larreta pone entonces a un exiliado Godoy a rememorar e inclinar todas las sospechas hacia el heredero, el futuro Fernando VII, que, según sus deducciones, pretendía asesinar al ministro -antes que a la duquesa-. La novela juega con el misterio de la teoría del asesinato y baraja el nombre de un único sospechoso -el príncipe de Asturias-, pero, como en el género detectivesco, el asesino termina siendo el personaje más impensado. De este modo, no es sino hasta en el epílogo, con la carta del obispo, que se devela el verdadero autor: su hermana María Teresa, la esposa de Godoy, una noble que suma a su personalidad taciturna y solitaria las repetidas humillaciones y desplantes de su marido, a quien finalmente pretende envenenar, pero Cayetana termina accidentalmente ocupando su lugar.

Como la novela, la adaptación no sólo involucra al mismo Goya, sino que incluye la posibilidad de que el crimen lo hubiera cometido el propio príncipe de Asturias -personaje cuyos hechos demuestran, en el texto de Larreta, que era de una vileza superior a la de Godoy-. La interpretación fílmica asume estas sospechas con su maquiavélico y suspicaz discurso dirigido a Cayetana en la última cena: "Querida, eres una mujer adorable. Nos invitas a comer pescado y nos haces tragar sapos y culebras. ¿Es un ajuste de cuentas, Cayetana? Estoy seguro de que aquí todos desean la muerte de alguien [...] No hay político importante que no guarde un muerto en su armario. La vida es así en la política. Nadie puede reinar sin eliminar". Lo que ocurre es que el film, que combina el género histórico con el policiaco, aumenta el número de sospechosos. Incluye a Pepita y al primo de la duquesa, Carlos Pignatelli -que en la novela se desempeñan como personajes secundarios- y, como ocurría en Tatuaje, reserva la resolución del misterio para el final ${ }^{16}$. Como género que se basa en la novela de intriga criminal,

el autor desprende los datos o 'piezas informativas' que habrá de articular y dosificar en las etapas narrativas precedentes, cuidando que en ellas quede preservado siempre el misterio que sólo se desvelará en el último acto. [énfasis agregado] (Gubern 2002: 207).

El film recupera este principio para relatar en retrospectiva las autoconfesiones en primera persona de tres personajes (Goya, Godoy y Pepita), lo que contribuye a dilatar el suspense 
-aunque parte de la crítica periodística revisada condena esta acumulación de flash-baks que mella la unidad y hace parecer la existencia de dos películas más o menos independientes (la muerte de Cayetana y la exposición de cada uno de los posibles asesinos) ${ }^{17}$.

La noche anterior a su muerte, con motivo del festejo de la futura boda de su sobrina, Manuelita de Silva y Waldstein con el conde de Haro, la duquesa había reunido en su palacio a dieciséis elegantes invitados, muchos de ellos con un secreto y distinto motivo para cometer el asesinato -una suerte de actualización de las novelas de Agatha Christie-. En esta secuencia, Bigas -que como guionista ha tenido injerencia y libertad en la creación de la historia- se permite incluir su preferencia por lo gastronómico -aunque menos destacada, eso sí, que en producciones anteriores-: esta vez se trata de las ortolans, "unas pequeñas aves que se ceban en jaulas individuales y protegidas [sic] con un paño negro y que finalmente se ahogan en armagnac"; un plato que se toma con un paño o servilleta que cubre la cabeza del comensal, para saborear primero los aromas y luego chupar en solitario (García 1998: 9). El plano de conjunto de esta peculiar cena se antoja una extraña congregación, pero es un recurso que constituye una metáfora de la falsedad del ambiente, de los enmascaramientos que reinan en esos círculos.

Volavérunt gira así en torno al misterio del posible asesinato de la duquesa de Alba como sintomático de la descomposición de las cortes. Pero a diferencia de las cintas del género policiaco -la misma Tatuaje-, la película no lleva sino a sugerencias sobre la identidad del asesino, de entre los muchos personajes que tenían motivos para eliminar a Godoy. A Bigas le interesa menos descubrir al asesino que escudriñar las causas y circunstancias del misterio, manejando de tal forma los elementos -donde prácticamente se exonera al servicio, como en El ángel exterminador (1962), de Buñuel- que al espectador no le quede más remedio que sospechar de la nobleza como un medio promiscuo, corrupto y farsante. No es sino hasta las imágenes de la penúltima escena de Godoy y la reina María Luisa de Parma riendo en el lecho, seguida por una imagen del castillo que se encuadra desde un lento alejamiento de cámara a modo de cierre, donde la narración en over reproduce las sospechas colectivas de la identidad del autor del crimen, apuntando nombres pero sin acusaciones concretas. No obstante, ambos personajes se corresponden con los nombres que en una escena anterior había dado la condesa María Teresa de Borbón -menos frágil y de personalidad más fuerte que en la novela-. La adaptación volvería, de este modo, a modificar el final del texto literario, adecuándolo a una correspondencia con la atmósfera de ambigüedad que la historia se ha mostrado incapaz de resolver, como constan las últimas palabras de la narración en off: "El caso del posible asesinato de la duquesa de Alba fue oficialmente cerrado. La hipótesis del veneno fue rechazada por falta de pruebas. El pueblo, como siempre, se quedó con sus dudas y versiones. La más aceptada fue la de que la reina, con la ayuda de su médico, la envenenó lentamente y que Godoy lo consintió".

Porque también deja claro el carácter sacrificial de Cayetana en un crimen que podría haber tenido móviles políticos o afectivos de cualquiera de los enemigos de Godoy ${ }^{18}$ en el que ella no se concebía como el objetivo. Así que, según los relatos novelesco y cinematográfico, en el verano de 1802 no habría sido Manuel de Godoy, sino la infortunada duquesa quien terminó bebiendo el funesto líquido: una víctima compensatoria, como Bilbao, que paga por las faltas de otros -y no es desatinado proponer, en este sentido, cierto paralelismo con la virgen (es decir, un tipo de mártir) por la que ella misma no oculta su devoción y cuya efigie aparece en la primera secuencia-. La pasión -referida al tormento y a la muerte (de Jesucristo)- deriva de la otra acepción: como apetito o afición (aunque eso no le resta sentido de inmolación al personaje). 
Así pues, el mismo óleo contiene -adelanta- la prueba que habría motivado el asesinato, según la estilización de Bigas: desde el comienzo se presiente en el plano del mismo cuadro al que la película se acoge para su apertura a partir de una sobreimpresión del órgano sexual. Esta imagen es la misma a la que igualmente se recurre para el cierre, desde un plano del lienzo completo seguido de un lento acercamiento de cámara al órgano genital para, una vez encuadrado, realizar una inclinación vertical hasta dar un giro de unos $90^{\circ}$ y congelar la imagen por algunos segundos, como forma de subrayar la analogía de la forma del pubis con la silueta de la copa. Hay una asociación a la humedad de la vagina, pero también a la muerte -una vez más, como Bilbao-, porque su pubis guarda la forma de la misma copa -vaso en la novela- que se presume instrumento de envenenamiento. Con ello, se amplía el rango de interpretaciones del órgano sexual femenino: no sólo símbolo de vida, porque si bien el sexo le da las alas a Cayetana para volar, es el que le conduce a su aniquilación, ya que su personalidad desenfadada y abierta contrastó con su época y sociedad al punto tal de que le mereció envidias y enemigos en las cortes (entre ellos, la misma reina), como reconoce el director: "me parece muy poético que todo lo que pasó [...] fuera por culpa del 'volavérunt' de la duquesa" (En: Muñoz 1999: 73). La idea que Bigas plantea desde ese segundo largometraje histórico se refuerza en esta producción: la ligazón, una vez más, entre sexualidad femenina y muerte -mitológica afinidad entre Eros y Thanatos-. Ciertamente la mujer es símbolo de vida -por su función biológica-, pero en algunas (sobre todo iniciales) producciones del director aparece asociada a su opuesto. No por azar, para los griegos la muerte era femenina: Cloto, una de las tres Moiras, la que rompe el hilo de la vida.

De todo ello puede extraerse que la filmografía de Bigas Luna se destaca por el retrato de un círculo eclipsado ${ }^{19}$. El director no puede eludir un posicionamiento en torno a las clases sociales privilegiadas y manifestar cierta afinidad hacia los mineros, pescadores, prostitutas de la calle y demás obreros humildes en general. De ahí, en parte, la atracción hacia la figura -aun cuando sea secundaria- de Goya, un artista de baja extracción social ${ }^{20}$ o hacia Horty, el humilde minero reconvertido en contador de historias que, aun cuando sean mentira, queda redimido por su expresividad y sensibilidad. Y es justamente la afinidad del director catalán hacia sus personajes lo que lo hace enmarcarlos desde el prototipo del personaje perdedor que se reivindica desde el arte y la sensibilidad.

\section{Fichas técnicas}

\section{La camarera del Titanic}

Otros títulos: La femme de chambre du Titanic (francés)

1997

Coproducción francesa (60\%), española (20\%) e italiana (20\%)

Estreno en España: 24.10.1997

Productoras:

Tornasol Films, Mate Production, UGC YM (Francia),

France 2 Cinema (Francia), La Sept Cinéma (Francia),

Rodeo Drive (Italia), Wesdeutscher Rundfunk (Alemania)

Productores ejecutivos: Kenout Peltier, Gérard Crosnier, Massimo Ferrero

Dirección:

Bigas Luna 
Argumento:

Guión:

Fotografía:

Ambientación/ Decoración:

Vestuario:

Montaje:

Música:

Sonido:

Principales intérpretes:

Premios:

Duración:
Didier Decoin, basado en su novela homónima

Cuca Canals, Bigas Luna, Jean-Louis Benoit

Patrick Blossier (color)

Walter Caprara, Bruno Cesari

Franca Squarciapino

Kenout Peltier

Alberto Iglesias

Jean-Paul Mugel, Laurent Quaglio, Christian Fontaine

Olivier Martínez (Horty), Aitana Sánchez-Gijón (Marie), Romane Bohringer (Zoe), Aldo Maccione (Zeppe), JeanMarie Juan (Pascal), Didier Bezace (Simeon)

Festival Internacional de El Cairo (mejor película, mejor dirección, mejor guión), 1997

Cinematografía de la Generalitat, 1997

Goya (mejor guión adaptado, mejor vestuario), 1998

Círculo de Escritores Cinematográficos (mejor guión adaptado), 1998

$101 \mathrm{~min}$

Sinopsis:

En 1912, Horty, un minero francés, gana un premio que consiste en asistir a la partida del histórico transatlántico Titanic. Cuando está en la habitación del hotel, llama a su puerta una hermosa mujer llamada Marie que afirma ser camarera del buque y no tener dónde pasar la noche. Horty le propone compartir su pieza, pero cuando despierta, a la mañana siguiente, ella ya se ha ido. A su regreso a casa, es recibido por sus compañeros y su esposa, Zoe. Ante las peticiones de sus compañeros, empieza a narrar en el bar los detalles de una historia de amor y pasión que se adquiere carácter ritual para sus oyentes, lo que produce un deterioro en la relación con Zoe. Un día aparece Zeppe, un teatrero que lo recluta en su compañía itinerante. Tiempo después, se presenta sorpresivamente Marie para reclamar su porcentaje de participación en la historia: había naufragado, pero era una prostituta que, junto con su marido Pascal, recurría al engaño para robar a los incautos. Ante la reaparición, Zoe le entrega a Pascal el dinero de las entradas y Horty tiene un breve encuentro con Marie -elidido por el film-, pero regresa, victorioso, a concluir la función.

\section{Volavérunt \\ 1999}

Coproducción española (80\%) y francesa $(20 \%)$

Estreno en España: 01.10.1999 
Productoras:

Productor ejecutivo:

Dirección:

Argumento:

Guión:

Diálogos adicionales:

Fotografía:

Ambientación/Decoración:

Vestuario:

Montaje:

Música:

Sonido:

Principales intérpretes:

Premios:

Duración:
M.D.A. Films, Mate Production, UGC YM (Francia), en asociación con UGC International (Francia), con la participación de Vía Digita, Canal Plus (Francia), con la colaboración de Televisión Española (TVE)

Mate Cantero

Bigas Luna

Antonio Larreta, basado en su novela homónima

Bigas Luna, Cuca Canals

Jean-Louis Benoit

Paco Femenía (color)

Luis Vallés "Koldo"

Franca Squarciapino

Kenout Peltier

Albert García Demestres

Gilles Ortion, Albert Manera, Ricard Casals

Aitana Sánchez-Gijón (duquesa de Alba), Jorge Perugorría (Francisco de Goya), Jordi Mollà (primer ministro Godoy), Penélope Cruz (Pepita Tudó), Stefania Sandrelli (reina María Luisa de Parma), Zoe Berriatúa (príncipe Fernando de Asturias), María Alonso (duquesa de Chinchón)

Concha de Plata del Festival Internacional de Cine de San Sebastián (mejor actriz, Aitana Sánchez-Gijón), 1999

$90 \min$

Sinopsis:

Mientras que Cayetana, la duquesa de Alba, está de viaje por tierras andaluzas, su amante, Manuel de Godoy, príncipe de la Paz, tiene encuentros sexuales con la humilde Pepita Tudor. En un taller de los palacios de la duquesa realiza sus obras Francisco de Goya, que había recibido el encargo de pintar las majas para Godoy, también amante de la reina María Luisa de Parma. A la mañana siguiente de una cena ofrecida en su palacio, Cayetana aparece muerta. Las investigaciones oficiales dictaminan la ejecución del suicidio, pero ello da inicio a una serie de confesiones: Goya cree que un descuido de su parte habría causado el envenenamiento por los elementos químicos de sus pinturas. Godoy, en cambio, mantiene que los móviles serían políticos y que el veneno habría estado dirigido por su enemigo el príncipe Fernando de Asturias. Pepita, por su parte, admite haber vertido el líquido en la copa para que éste la bebiera, pero arrepentirse en el momento último. Finalmente, según la versión de la duquesa de Chinchón, esposa de Godoy, Cayetana murió envenenada por la reina, con la ayuda del doctor que atendía a la duquesa, situación de la que su propio esposo estaba enterado. 


\section{Notas}

1. Que el mismo Bigas reconoce al contraponer la labor de un historiador con la de un creador: "'Un creador [...] es lo opuesto a un historiador. Un historiador busca la verdad y el creador es un embustero, es el que está constantemente alterando la realidad. El creador parte de esa realidad pero luego la altera" (En: García 1998: 8).

2. Que evidentemente no representa un indicador del erotismo, como expresa Lenne: "El erotismo es lo que se desarrolla 'en la cabeza', es una función cerebral. [...] El erotismo son los fantasmas, es decir, representaciones imaginarias” (En: Freixas y Bassa 2000: 24).

3. Desde mucho antes de su estreno, Titanic (1997) de James Cameron estuvo promocionándose a nivel mundial como una de las producciones más costosas del cine. Pese al contraste de presupuestos, $L a$ camarera del Titanic fue, en su momento, una de las películas más caras del cine español: 1.600 millones de pesetas, aunque la diferencia con respecto a la producción anglosajona -de casi 25.000- no dejaba de ser abismal (Hermoso 1997: 60). Aun así, la situación presagiaba, para Manuel Montero, una lucha de 'Titanics', con base en el razonamiento de que el público no estaría dispuesto a pagar asistencia a dos films -aun cuando fueran muy distintos- con el mismo nombre en el título (1997: 51).

4. De manera semejante al film, cuya producción, ambientación e interpretaciones procedían de las tres regiones que conformaban la antigua región del Lacio.

5. Del mismo modo que durante la carrera exprime al máximo su resistencia -por eso gana la prueba-, le da luego el mismo uso a la imaginación -por eso gana al público-.

6. La novela verbaliza este fervor de devoción en el que la profanación viene dada por la enunciación del discurso: "Con la mirada fija en la foto de Marie, que había colocado sobre la mesa, se convirtió en su propio oyente, avanzando en su historia con una especie de fascinación alucinada. Las primeras palabras de profanación que pronunció le hicieron daño. Pero enseguida, a medida que los vasitos de ginebra se sucedían, se animó. La mirada ausente de Marie lo alentaba” [énfasis agregado] (Decoin 1996: 120-121).

7. En la novela, el ambiente es mucho más descarnado: sólo en la competencia que da inicio al texto, los trabajadores cargan becerros (cuyo orín de pánico se confunde, en las espaldas de los concursantes, con su sudor y la lluvia), tras haber sido desoída la petición en la que solicitaban su sustitución por una carga equivalente pero inerte (como sacos de arena, igual que en la película), "pues el fundador del concurso quería que fuese forzosamente un becerro" (Decoin 1996: 12), ya que un animal vivo le infundiría un sentido de espectacularidad.

8. Como Mr. Cheapman, el molesto e indisciplinado pasajero del Titanic; Sciarfoni, quien le compra a Horty la foto de Marie que luego éste recupera por la fuerza, y Aïcha, la sirvienta musulmana del bar que le da cobijo e intimidad en su desván durante el tiempo en que se oculta de la furia del italiano. La anulación de personajes es parte de cualquier reinterpretación, consonante con la premisa básica de la imposibilidad de un texto fílmico de duración estándar de contener la totalidad de la historia narrada (Sánchez Noriega 2000: 54).

9. La cual, ante la utilitaria pregunta de Sierra sobre el provecho de su marido, “Cómo puede gustarte un hombre que no sabe ni ganar dinero?", le responde radical: "Sabe contar historias".

10. De este modo, Zoe cae en una trampa similar en la que había sido involucrada, puesto que Horty responde a un rumor -el que la vinculaba con Simeón- con un discurso de naturaleza semejante, inscrito en el ámbito de la invención, en el que toda verificación se revela imposible. 
11. Cabe recordar que en la adaptación del guión de La camarera del Titanic participó también Bigas Luna, lo que permite arrojar luz sobre las coincidencias en los parlamentos de ambos protagonista.

12. Para los antiguos, esta especie de tritón tenía la propiedad de vivir en el fuego sin consumirse (Chevalier y Gheebrant 1998: 908). Como icono está presente también en los zarcillos de Rita, la primera novia de Benito González, quien, al igual que Marie, es el (involuntario) motor de las conductas de los personajes masculinos, aunque ambas resultan muy distintas de lo que éstos esperaban. Manifestación viviente del fuego, el simbolismo de la salamandra es paradójico -como perennidad (de la pasión) y como combustible (su frialdad por su poder de apagar el fuego)-, lo mismo que los efectos de cada una, en un caso hacia la autodestrucción y en otro hacia la autorredención.

13. Bigas confiesa que esta vez no ha querido reproducir más imágenes de Goya: "En los tiempos en que transcurre la acción, él vive mucho en palacios, comparte manteles con la nobleza" (En: Bonet Mojica 1998b: 60).

14. Según le escribe a Godoy en la esclarecedora carta del epílogo: "Cada vez que lo veo [el grabado] pienso en el alma de Mayte, que siempre cifró su vuelo en el tenue aleteo de las mariposas de su infancia, en el suave, tibio y susurrante misterio de nuestra adolescencia compartida, y no pudo, por más impulso que tomara para despegar del suelo, conjurar los monstruos de su camino: el mundo, el demonio, la carne, todo lo que tú convocaste en su vida sin proponértelo" (Larreta 1999: 261).

15. Lo que guarda una ligera alusión al desvanecimiento de Marie tras el acto sexual (por lo demás reforzado con la presencia de la actriz que interpreta ambos papeles).

16. Que en el rodaje, el director quiso mantener en secreto aun hasta dentro de su propio equipo de producción (Bonet Mojica 1998b: 57).

17. El ordenamiento secuencial a cargo de Bigas Luna y Cuca Canals ha sido probablemente el componente más cuestionado por la prensa (Fernández-Santos 1999b: 37; Bonet Mojica 1999a: 73, 1999b: 55 y Vicente 1999: 30-31).

18. Quien a su vez sería luego víctima, junto con el exministro Jovellanos, de un intento de envenenamiento, por lo demás, arma común de asesinato de la época.

19. Una burguesía decadente en Bilbao e incestuosa en Caniche que evoluciona hacia una posición del director más comprometida en los sobrentendidos señores feudales de Jamón jamón o el trepador corrupto de Huevos de oro.

20. La excepción vendría dada por Cayetana, que a pesar de su condición de noble, se describe como una mujer sensible antes que típicamente frívola, con una benevolencia incluso un tanto mayor de lo que lo hace la novela, que acentúa su carácter entre frívolo y caprichoso -como su decisión de recuperar uno de sus palacios, hecho que la impopularizó ante sus vasallos, en tanto que la película solamente habla de intentos -no detallados- de quemar el castillo. La película, ciertamente, la describe con mayor benevolencia de lo que lo hace la novela: "una de las mujeres más bellas, generosas, ricas y liberadas de su época" con "una gran sensibilidad hacia los más desfavorecidos", según Bigas (1999: s. p.) -por eso en una de las categorizaciones se le postula como el eros sociata (Sáinz 1994: 240)-.

21. El texto de Larreta alude a la estampa campesina del pintor, cuya habla destacaba por su llaneza e incorrecciones lingüísticas. 


\section{Bibliografía}

Aumont, Jacques y Marie, Michel. 1993. Análisis del film. $2^{\mathrm{a}}$ ed. Barcelona: Paidós.

Aumont, Jacques et al. 1996. Estética del cine. $2^{\mathrm{a}}$ ed. Barcelona: Paidós.

Barthes, Roland.1974. El placer del texto. México: Siglo XXI.

1997. Fragmentos de un discurso amoroso. $13^{\mathrm{a}}$ ed. Madrid: Siglo XXI.

Bassa, Joan y Ramon Freixas.1996. Expediente "S". Softcore, Sexploitation, Cine "S". Barcelona: Futura.

Bataille, Georges. 1997. El erotismo. Barcelona: Tusquets.

Baudrillard, Jean. 1989. De la seducción. Madrid: Cátedra.

1997. Las estrategias fatales. Barcelona: Anagrama.

Borau, José Luis (dir.). 1998. Diccionario del cine español. Madrid: Alianza.

Casetti, Francesco y Federico Di Chio. 1998. Cómo analizar un film. Barcelona: Paidós.

Català, Josep Maria. 2002. Notas del curso doctoral Imagen y conocimiento: una introducción histórica a la visualización del saber, Facultat de Comunicació Audiovisual de la Universitat Autònoma de Barcelona, 15.02-03.05.

Chevalier, Jean y Alain Gheebrant. 1998. Diccionario de los símbolos. $2^{\mathrm{a}}$ ed. Barcelona: Herder.

Decoin, Didier. 1996. La camarera del Titanic. Barcelona: Ediciones B.

Eliade, Mircea. 1988. Tratado de historia de las religiones. $6^{\text {a }}$ ed. México: Era.

Freixas, Ramon y Joan Bassa. 2000. El sexo en el cine y el cine de sexo. Barcelona: Paidós.

Gubern, Román (1974) et al. 1997. Historia del cine español. $2^{\mathrm{a}}$ ed. Madrid: Cátedra.

Gubern, Román. 2000. El eros electrónico. Madrid: Taurus.

2002. Máscaras de la ficción. Barcelona: Anagrama. 
Kristeva, Julia. 1978. El texto de la novela. Barcelona: Lumen.

Larreta, Antonio. 1999. Volavérunt. Barcelona: Planeta.

Latour, Bruno. 1998. "Visualización y cognición: pensando con los ojos y con las mano". En: La Balsa de la Medusa, 45- 46.

May, Rollo. 1998. La necesidad del mito. Barcelona: Paidós.

Metz, Christian. 2001. El significante imaginario. Barcelona: Paidós.

Morin, Edgar. 2001. El cine o el hombre imaginario. Barcelona: Paidós. (Edición Original: Seix Barral, 1972).

Morris Desmond. 2005. La mujer desnuda. Barcelona: Planeta.

Paas-Zeidler, Sigrun. 1980. Goya. Caprichos. Desastres. Tauromaquia. Disparates. Barcelona: Gustavo Gili.

Pérez Perucha, Julio (ed.). 1997. Antología crítica del cine español 1906-1995. Madrid: Cátedra.

Pisano, Isabel. 2001. Bigas Luna: sombras de Bigas, luces de Luna. Madrid: Sociedad General de Autores y Editores.

Romaguera i Ramió, Joaquim (dir.). 2005. Diccionari del cinema a Catalunya. Barcelona: Enciclopèdia Catalana.

Sáinz, Salvador. 1994. El cine erótico. Madrid: Royal Books.

Sánchez, Alberto (ed.). 1999. Bigas Luna. La fiesta de las imágenes. Huesca: Gráficas Alós.

Sánchez Noriega, José Luis. 2000. De la literatura al cine. Barcelona: Paidós.

2002. Historia del cine. Teoría y géneros cinematográficos, fotografía y televisión. Madrid: Alianza.

Tyler, Parker. 1973. Cine underground. Barcelona: Planeta.

Vanoye, Francis. 1996. Guiones modelo y modelos de guión. Barcelona: Paidós.

Vázquez Montalbán, Manuel. 1997. Tatuaje. Barcelona: Planeta. 


\section{Prensa}

Anónimo. 2002. "16 maneras de dirigir sexo" En: Fotogramas. 55 (junio): 96.

Biga Luna. 1999. "Volavérunt según Goya”. En: La Vanguardia.

Bonet Mojica, Lluís. 1983. "El cineasta catalán Bigas Luna estrena hoy su film Renacer, rodado en Tejas". En: La Vanguardia: 56.

1993. "El increíble falo menguante". En: La Vanguardia: 53.

1998a. "Nadie implicado en el rodaje de la película sabrá quién mató a la duquesa de Alba". En: La Vanguardia: 57, 62.

1998b. "“Cada personaje del film tiene un motivo para haber asesinado a la duquesa de Alba"'. En: La Vanguardia: 56, 60.

1999a. "El exceso de expectativas perjudica a Volavérunt, un Bigas Luna de perverso preciosismo". En: La Vanguardia: 73.

1999b. "Lucientes cuadros de pasión". En: La Vanguardia: 55.

Cabeza, Elisabet. 1999. "Volavérunt és un 'thriller' històric, un divertit viatge al passat". En: Avui: 56.

Casas, Quim. 1997. “Después del naufragio”. En: El Periódico: 53.

EFE. 1991. "Las edades de Lulú, del catalán Bigas Luna, lanza a Francesca Neri en Italia". En: El Periódico: 50.

Egurbide, Peru. 1997. "Bigas Luna rueda en Italia su primer film romántico". En: El País: 34.

Fernández-Santos, Ángel. 1997. "El desquite de Bigas Luna”. En: El País: 43.

1999. "Bigas Luna reduce el enigma de Goya y la duquesa de Alba a un soporífero galimatías". En: El País: 37.

Flury, Victor. (s.f.). "Mentiras verdaderas”. En: La Nación.

García, Rocío. 1998. "Bigas Luna se sumerge en las intrigas del XVIII”. En: El País: 8- 9.

Hermoso, Borja. 1997. "El Titanic simboliza el hundimiento de nuestro siglo". En: El Mundo: 60. 
Llopart, Salvador. 1997. "Bigas vuelve romántico con La camarera del Titanic". En: La Vanguardia: 41, 55.

Martí Font, Josep Maria. 1996. “Bigas Luna: 'En Bambola busqué el exceso”. En: El País: 37.

Memba, Javier. 1993. "Un cineasta underground". En: El Mundo: 39.

Montero, Manuel. 1997. "Bigas cambia de rumbo con Aitana”. En: El Periódico: 51.

Muñoz, Diego. 1999. “Bigas Luna: ¿№ es divertido que Godoy le haga pedorretas a la reina de España?”. En: La Vanguardia: 73.

Vicente. 1999. “Volavérunt, de Bigas Luna. Intriga en la corte”. En: Cartelera Turia: 30- 31. 